\title{
Productivity Analysis of Crude Palm Oil (CPO) in PT. Ramajaya Pramukti Using Value Stream Mapping Approach
}

\author{
Dhimas Budhi Pratama, ${ }^{\mathrm{a}, *}$ and Anita Susilawati ${ }^{\mathrm{a}}$ \\ a) Mechanical Engineering Department, Universitas Riau, Indonesia \\ *Corresponding author: dhimas.pratama1997@gmail.com
}

\section{Paper History}

Received: 25-August-2021

Received in revised form: 20 -October-2021

Accepted: 30-November-2021

\begin{abstract}
This study aims to analyze the productivity of CPO processing using Value Stream Mapping (VSM) approach. A case study conducted in PT. Ramajaya Pramukti, Indonesia. The research method used the VSM and Process Activity Mapping (PAM) to determine wastes in the process flow of CPO production. The data was collected in 1 month. The preliminary result of CPO productivity process was average of $73.67 \%$. Based the Future Value Stream Mapping (FVSM) the CPO processing time can be efficient from 1.981 seconds $/ \mathrm{kg}$ to 1.963 seconds $/ \mathrm{kg}$. The productivity processing for value added 1.525 seconds $/ \mathrm{kg}$, which non value added of 0.012 and the non necessary value added of 0.383 seconds $/ \mathrm{kg}$. The quality of raw materials was the biggest waste contributor. It was caused a longer processing time due to poor quality of raw materials.
\end{abstract}

KEY WORDS: Crude Palm Oil, Value Stream Mapping, Analytical Hierarchy Process.

\subsection{INTRODUCTION}

To maintain the company's existence, various strategies and policies are carried out so that increasing productivity and efficiency of the company encourages companies to win in market competition [1-3]. In the process of processing Fresh Fruit Bunches (FFB) into Crude Palm Oil (CPO) there is the waste that can reduce the productivity and efficiency of company's products [4]. The company's efficiency is threatened to decrease due to waste, which can be eliminated by adoption of lean manufacturing approaches [5-7]. Lean manufacturing is a systematic approach to identify and eliminate waste through continuous improvement, in order to create an optimal production process flow with fast lead times and minimal waste [8-9]. One of the lean manufacturing tool and technique to efficient and effective the production process is Value Stream Mapping (VSM).

The value stream mapping method is a lean mapping method to see the process flow and information flow in the production process [10-11]. This technique has been widely used because of its ability to collect, analyze and present information in a short time [12]. The main purpose of this method is to identify the type of waste [13-14]. Waste can be defined as all work activities that do not provide added value in the process of transforming inputs into outputs along the value stream mapping. Waste is classified into overproduction, waiting, transportation, improper processing, useless inventory, useless movement and defects in the Toyota Production System $[12,15]$.

Activities that occur in the production process (Hines \& Taylor, 2000) [16]: (1) value adding activity, is an activity that is able to provide added value to a product, (2) non value adding activity, is an activity that does not provide added value to a product. a product. This activity is included in the (waste) that must be eliminated in the production system, (3) necessary non value adding activity, namely activities that do not add value to the product, but this activity is needed in existing production procedures or processes. The Value Stream Mapping (VSM) method can be used to increase the productivity of CPO processing [14]. It can be evaluated the performance of production process of $\mathrm{CPO}$ to find out the causes of waste. Therefore, it can be evaluated in the production processes; there is no waste of time, material that occurred in manufacturing process of CPO in the company.

PT. Ramajaya Pramukti is one of the agro-industrial companies (plantations and palm oil mills) that produce the CPO and palm kernel. Problems or waste that arise at PT. Ramajaya Pramukti occurs in the production process, namely the time for the next production process from the previous process, thus causing a waste of time so as to reduce productivity. The problem of production time in the form of palm fruit at the sorting station because workers who supply palm fruit from the sorting station to the ramp loading station do not have a standard time when the palm fruit must be supplied to the loading ramp station and the old lorry is sent from the threshing station to the loading ram. The time for company's standard boiling is 90 minutes, while in the field it takes a boiling cycle of up to 111 minutes. This is due to the poor quality of raw materials so that it requires a longer boiling 
time than the company's provisions. In this paper is conducted to analyze the productivity of CPO processing in PT. Ramajaya Pramukti based the lean manufacturing approach, namely the VSM (Value Stream Mapping).

\subsection{METHOD}

In this $\mathrm{CPO}$ productivity analysis research using quantitative methods by making direct observations at PT. Ramajaya Pramukti, Riau Province. Data collection was carried out on November 23 to December 03, 2020. The workstations that were used as objects of research were: weighing, sorting, loading ramp, sterilizer (boiling), shelling, pressing, purification and storage

\subsection{Data Collection}

The data needed in this study were:

- Primary data is data obtained from direct observation and research in the field. Primary data collection was carried out by observing directly at the research site and interviewing operators who were directly involved in operations to obtain information. The data collection was carried out such as the number of FFB that can be processed and $\mathrm{CPO}$ produced on each work shift and on every working day (2 shifts). Effective working time on the production floor of PT. Ramajaya Pramukti was 25 working days/month (Monday to Saturday) with a total of 9 hours/shift. The data collection method for processing time at each station was repeated 10 times in 1 workstation using a stopwatch. Data retrieval to determine the cause of waste was done by interviewing the operator and direct observation at each station.

- Secondary data comes from documents and archives as supporting primary data in research. This data was from the company documentation. The data was collected the composition of fresh fruit bunches at PT. Ramajaya Pramukti. It was used to determine the amount of CPO that should be produced from the amount of FFB processed to be compared with that produced in the field. Then, the data collected was working shifts at PT. Ramajaya Pramukti to find out how much FFB can be processed and the amount of $\mathrm{CPO}$ produced per work shift.

\subsection{Data Processing}

The stages of data processing carried out in this study were calculated the processing time of $\mathrm{CPO}$, followed by making Current Value Stream Mapping (CVSM). More, It was conducted the Process Activity Mapping (PAM) on CPO Processing and identification of cause-and-effect diagrams (fishbone). Finally, it was made the Future Value Stream Mapping (FVSM) and calculating the productivity of the resulting $\mathrm{CPO}$.

\subsection{RESULT AND DISCUSSION}

Based the data results of time process for each station with a total weight of FFB $676,759 \mathrm{~kg}$, for a working time of 2 shifts (18 hours) can be seen in Table 1 .

Table 1: Data of process time at each station

\begin{tabular}{clc}
\hline No & \multicolumn{1}{c}{ Station } & Process Time \\
\hline 1 & Weighing & 0.097 seconds $/ \mathrm{kg}$ \\
2 & Sorting & 0.097 seconds $/ \mathrm{kg}$ \\
3 & Loading Ramp & 0.136 seconds $/ \mathrm{kg}$ \\
4 & Sterilizer & 0.059 seconds $/ \mathrm{kg}$ \\
5 & Threshing & 0.134 seconds $/ \mathrm{kg}$ \\
6 & pressing & $0.142 \mathrm{~seconds} / \mathrm{kg}$ \\
7 & Purification & $0.227 \mathrm{~seconds} / \mathrm{kg}$ \\
8 & Storage Tanks & $0.547 \mathrm{~seconds} / \mathrm{kg}$ \\
\hline
\end{tabular}

From Table 1, it is found that the entire time process of FFB processing into CPO. Based data in Table 1 was constructed the

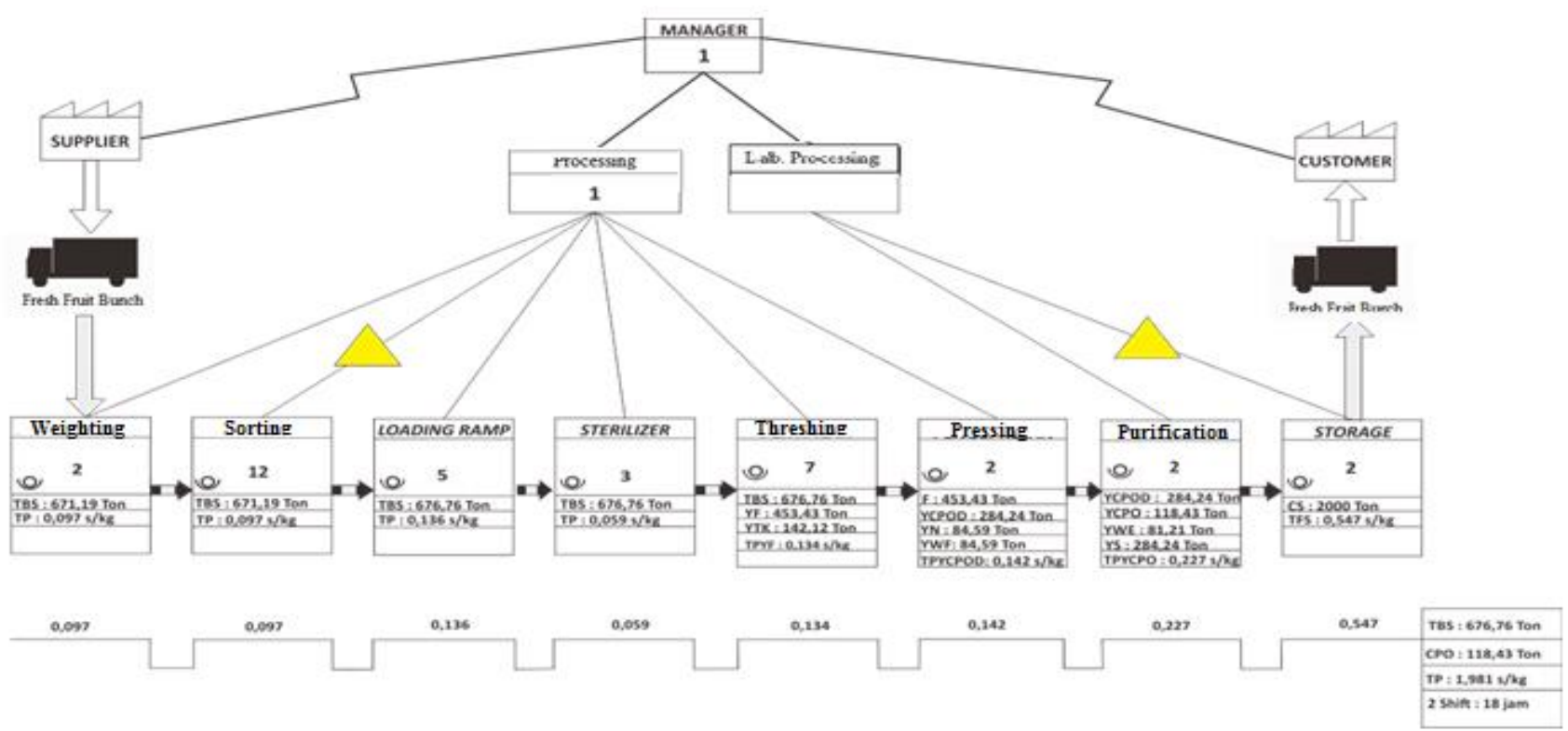

Figure 1: Current value stream mapping in case study company 
Current Value Stream Mapping (CVSM). The current value stream mapping is the starting point to identify the process flow before making improvements. The CVSM is a tool to describe a system as a whole along with the value stream contained in the company. According the current value stream mapping, information and physical flow in the system can be known. The required process time for each work station for the CVSM in the company that can be seen in Figure 1 .

After the CVSM was obtained, then a description of Process Activity mapping that was constructed, which the PAM method functions to identify activities that occur (value added, non value added and necessary non value added). The PAM result is depicted in Figure 2.

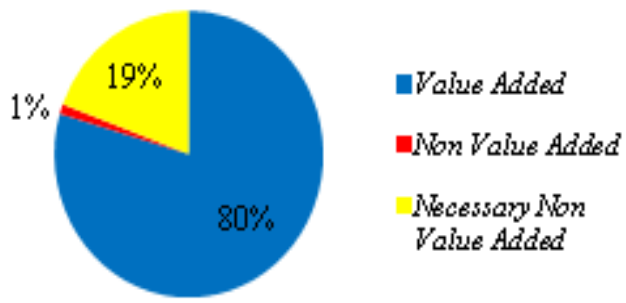

Figure 2: Percentage of time on the production floor

The next stage was to design the Future Value Stream Mapping (FVSM) that supports the proposed improvement. With the application of Future Value Stream Mapping, it is expected to reduce production time, so as to increase productivity in CPO processing at PT. Ramajaya Pramukti. The Future Value Stream Mapping was based on the Current Value Stream Mapping, then the result analyzing for the recommendations might be given. The time comparison between CVSM and FVSM can be seen in Table 2 .
Table 2: The productivity comparison, CVSM versus FVSM

\begin{tabular}{ccc}
\hline Comparison & Current VSM & Future VSM \\
\hline FFB processed & $676,759 \mathrm{~kg}$ & $676,759 \mathrm{~kg}$ \\
CPO produced & $118,430 \mathrm{~kg}$ & $128,580 \mathrm{~kg}$ \\
Total processing time & $1.981 \mathrm{~s} / \mathrm{kg}$ & $1.920 \mathrm{~s} / \mathrm{kg}$ \\
Total VA & $1.576 \mathrm{~s} / \mathrm{kg}$ & $1.568 \mathrm{~s} / \mathrm{kg}$ \\
Total NVA & $0.022 \mathrm{~s} / \mathrm{kg}$ & $0.012 \mathrm{~s} / \mathrm{kg}$ \\
Total NNVA & $0.383 \mathrm{~s} / \mathrm{kg}$ & $0.383 \mathrm{~s} / \mathrm{kg}$ \\
\hline
\end{tabular}

From the comparison between the processing time of CVSM and FVSM, the CPO productivity value can be calculated used the formula [13-15] below:

$$
\begin{aligned}
\text { Productivity of CPO (\%) } & =\frac{\text { Resulting CPO productivity }}{\text { Planning CPO productivity }} \times 100 \% \\
& =\frac{118.43 \mathrm{Ton}}{171 \mathrm{Ton}} \times 100 \% \\
& =69.26 \%
\end{aligned}
$$

\begin{tabular}{|c|c|c|c|c|c|}
\hline No & $\begin{array}{l}\text { Year } \\
2020\end{array}$ & $\begin{array}{c}\text { Total } \\
\text { TBS } \\
\text { (Ton) } \\
\end{array}$ & $\begin{array}{c}\mathrm{CPO} \\
\text { produced } \\
\text { (Ton) }\end{array}$ & $\begin{array}{c}\text { Target } \\
\text { CPO of } \\
\text { company }\end{array}$ & Productivity \\
\hline 1 & 23 Nov. & 677 & 118.43 & 171 & $69.26 \%$ \\
\hline 2 & 24 Nov. & 762 & 133.43 & 171 & $78.03 \%$ \\
\hline 3 & 25 Nov. & 821 & 143.69 & 171 & $84.03 \%$ \\
\hline 4 & 26 Nov. & 758 & 132.57 & 171 & $77.53 \%$ \\
\hline 5 & 27 Nov. & 493 & $86.23 \mathrm{~T}$ & 171 & $50.43 \%$ \\
\hline 6 & 28 Nov. & 398 & $69.65 \mathrm{~T}$ & 171 & $40.74 \%$ \\
\hline 7 & 30 Nov. & 832 & 145.59 & 171 & $85.14 \%$ \\
\hline 8 & 01 Dec. & 838 & 146.60 & 171 & $85.74 \%$ \\
\hline 9 & 02 Dec. & 842 & 147.27 & 171 & $86.13 \%$ \\
\hline 10 & 03 Dec. & 778 & 136.23 & 171 & $79.67 \%$ \\
\hline
\end{tabular}

The value of CPO productivity was obtained in the field can be seen in Table 3.

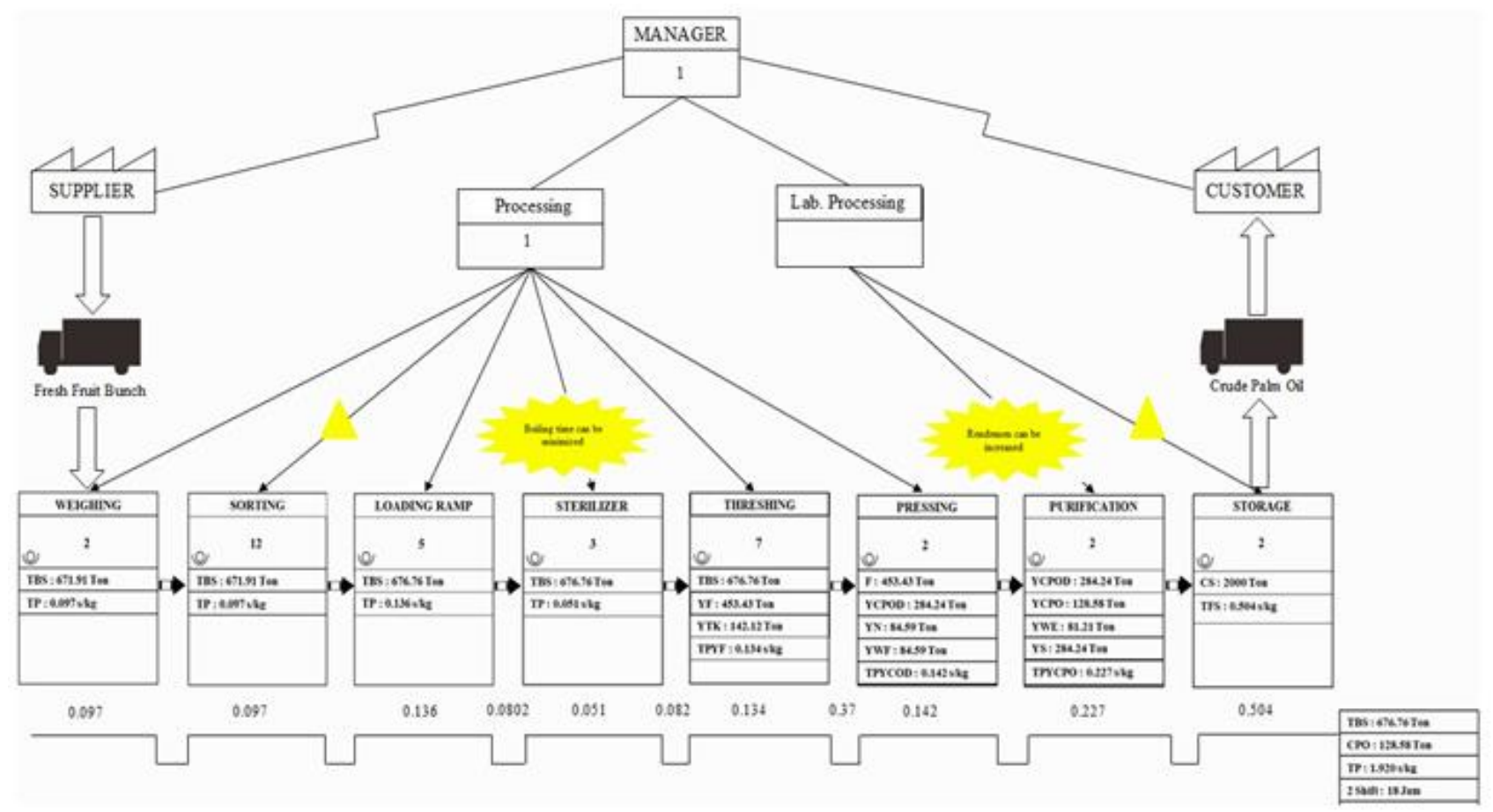

Figure 3: Future Value Stream Mapping (FVSM) in case study company 
It can be seen in Table 3 the productivity value of CPO processing with an average of $73.67 \%$. This result was obtained from improvements that were made to several stations (sorting, loading rams, sterilizer stations, purification stations and storage stations).

In the sorting of work station occurred the waste due to the quality of raw FFB was not good. Sequences, that can increased the processing time for FFB to CPO. Then, the producing oil was not according to company standards. In addition, the quality of raw materials can be caused a longer processing time at the weighing and sorting stations due to poor quality of raw materials. That might be solved by applying the automatic separation system using microcontroller to separate the raw palm fruits based on the level of the palm fruit's maturity [17].

In the loading ramp station, that occurred the waste such the raw materials processed were poor quality. It would be cause a longer boiling time for fresh fruit bunches and the use of steam to boil more consumptive. If the poor quality of the raw material that was processed, it make difficult to separate the shell from the fiber of palm fruit. So, there were still a lot of fibers attached to the shell, which difficult to break the shell seeds. The poor quality raw materials also contain a small amount of oil.

According the FVSM in the sterilizer station, the boiling time was improved from 6,210 seconds per cycle to 5,400 seconds per cycle. This can be done with good quality of raw materials (FFB maturity level) and the pressure achieved. At the refining station of $100 \%$ processed FFB, there was only $17.5 \%$ CPO (PT. Ramajaya Pramukti). This amount can be changed to $19 \%$ by improving the boiling time of FFB, because the proper boiling time (according to the standard) would reduce the amount of water content in the oil and also the amount of oil attached to the sludge. Beside, to improving the boiling time, the company must also supply more FFB, which contains more $\mathrm{CPO}$ yields than the duration type of FFB.

\subsection{CONCLUSION}

There are several wastes that occur in CPO processing at PT. Ramajaya Pramukti, namely the factors of raw materials, motion, work machines/equipment, work environment and methods used in doing the work. Raw materials are a factor that greatly influences the waste that occurs, because the quality of the raw materials obtained is not good, it will prolong the processing time such as sorting and boiling. Based the Future Value Stream Mapping (FVSM), it is found that the processing time of Fresh Fruit Bunches (FFB) into Crude Palm Oil (CPO) at PT. Ramajaya Pramukti. The FFB processing of $676,759 \mathrm{~kg}$ obtained the processing time of 1.981 seconds $/ \mathrm{kg}$ with a value added of 1.576 seconds $/ \mathrm{kg}$, non-value added 0.022 seconds $/ \mathrm{kg}$ and necessary non value added of 0.383 seconds $/ \mathrm{kg}$. For the processing time of 1.963 seconds $/ \mathrm{kg}$ with value added 1.568 seconds $/ \mathrm{kg}$, non value added 0.012 seconds $/ \mathrm{kg}$ and necessary non value added of 0.383 seconds $/ \mathrm{kg}$. Then, the productivity value was obtained in CPO processing at PT. Ramajaya Pramukti on 23 November 2020 to 03 December 2020 with an average of $73.67 \%$. While, the waste time in the CPO processing from 23 November 2020 to 03 December 2020 was $26.33 \%$.

\section{ACKNOWLEDGEMENTS}

The Authors would like to thank to the Managers and all Staff in PT. Ramajaya Pramukti who has helped a lot in the form of knowledge, experience and supporting when collecting data in the field.

\section{REFERENCES}

[1] Roghanian, P., Rasli, A. \& Gheysari, H. (20212) Productivity through effectiveness and efficiency in the banking industry, Procedia - Social and Behavioral Sciences, 40, 550-556.

[2] Susilawati, A. (2021). Productivity enhancement: lean manufacturing performance measurement based multiple indicators of decision making. Production Engineering Research Development. $15,343-359$ https://doi.org/10.1007/s11740-021-01025-7.

[3] Prakash, A., Jha, S., Prasad, K. \& Singh, A. (2017). Productivity, quality and business performance: an empirical study, International Journal of Productivity and Performance Management, 66, 78-91. 10.1108/IJPPM-032015-0041.

[4] Yunita, F. (2015). Production Efficiency of CPO (Crude Palm Oil) at PT. Agro Masang Perkasa Plantation Unit Palm Oil Mill in Agam Regency. Payakumbuh State Agricultural Polytechnic.

[5] Paramawardhani, H., \& Amar, K. (2020). Waste identification in production process using lean manufacturing: A case study. Journal of Industrial Engineering and Halal Industries, 1(1), 39-46.

[6] Pujotomo, D. \& Raditya, A. (2011). Application of lean manufacturing to reduce waste in SME scale industries, Journal of Industrial Engineering, 6 (3), 137-146.

[7] Susilawati, A., Tasri, A. \& Arief, D.S. (2019). A framework to improve equipment effectiveness of manufacturing process - a case study of pressing station of crude palm oil production, Indonesia, IOP Conference Serries: Material Science. Engineering, 602012041.

[8] Dixit, Abhishek \& Dave, Vikas \& Singh, Alakshendra. (2015). Lean Manufacturing: An Approach for Waste Elimination. International Journal of Engineering Research and. V4. 10.17577/IJERTV4IS040817.

[9] Poksinska, B. \& Swartling, D. (2018). From successful to sustainable Lean production - the case of a lean prize award winner, Total Quality Management \& Business Excellence, 29(9-10), 996-1011.

[10] Seth, D., Seth, N. \&Goel, D. (2007). Application of value stream mapping for minimization of wastes in the processing side of supply chain of cottonseed oil industry in Indian context, Journal of Manufacturing and Technology, 19, 529-550.

[11] Susilawati, A., Sarwar, M., Darji, T. \& Agusti, N. (2021). Analysis of production process in small business using value stream mapping approach. Journal of Ocean, Mechanical and Aerospace -Science and Engineering-, 65(1), 31-35. doi:10.36842/jomase.v65i1.235.

[12] Hines, P. \& Rich, N. (1997). The seven value stream mapping tools, International Journal of Operations \& Production Management, 17(1), 46-64. 
(c) 2012 ISOMAse, All rights reserved

[13] Doğan, Nuri Özgür \& Simsek Yagli, Burcu. (2019). Value Stream Mapping: A Method That Makes the Waste in the Process Visible. 10.5772/intechopen.83798.

[14] Sholihin, M. (2018). Analysis of Crude Palm Oil (Cpo) Productivity Using the Value Stream Mapping (VSM) Method (Case Study: PTPN V Sei. Galuh, Kampar, Riau). Riau University, Riau.

[15] Toyota Motor Corporation. 2006. Toyota Production System: Kaizen Standardization of Work. Jakarta (ID):
Pustaka Binaman Pressindo.

[16] Hines, P. \& Taylor, D. (2000). Going Lean. Lean Enterprise Research Centre Cardiff Business School, Cardiff, UK, 3-43.

[17] Arief, D.S., Fitra, E., Minarni, M., Herman, H. \& Salambue, R. (2018). Modeling of control system on sorting palm fruit machine by using arduino microcontroller, Journal of Ocean, Mechanical and Aerospace -Science and Engineering-, 52(1), 1-5. 